\title{
Partial Least Square-Structural Equation Modeling pada Tingkat Kepuasan dan Persepsi Mahasiswa terhadap Perkuliahan Online
}

\author{
Suriana*1, $^{* 1}$ Rahmawati ${ }^{2}$, Darma Ekawati ${ }^{3}$ \\ 1,2,3 Program Studi Matematika, Universitas Sulawesi Barat, Indonesia \\ e-mail: *11 surianaana50@gmail.com, 람ahmah@unsulbar.ac.id, ${ }^{3}$ darmaekawati@unsulbar.ac.id
}

\begin{abstract}
Abstrak
Pembelajaran secara online merupakan solusi terbaik terhadap kegiatan belajar mengajar di tengah pandemi COVID-19. Penyebaran COVID-19 secara global memberikan dampak di segala sektor, tidak terkecuali dalam dunia pendidikan. Seperti halnya pembelajaran yang dilakukan secara tatap muka/luring, pembelajaran daring ini memiliki beberapa kendala dalam pelaksanaannya, diantaranya dari kesiapan perangkat elektronik yang dibutuhkan, akses jaringan dan kesiapan peserta didik dalam melakukan adaptasi terhadap model pembelajaran ini. Penelitian ini bertujuan untuk menentukan tingkat kepuasan dan persepsi mahasiswa terhadap perkuliahan online dengan menggunakan Partial Least Square-structural Equation Modeling (PLS-SEM). Model yang dibentuk hanya terdiri dari tiga variabel laten eksogen yang menunjukkan persepsi mahasiswa yaitu aspek pembelajaran, aspek kompetensi dosen, dan aspek sarana dan prasarana serta dua variabel laten endogen yaitu tingkat kepuasan dan prestasi akademik. Data penelitian diperoleh melalui penyebaran kuesioner terhadap Mahasiswa Universitas Sulawesi Barat yang mengikuti perkuliahan secara online atau daring. Hasil analisis yang telah dilakukan menunjukkan bahwa aspek pembelajaran dan aspek sarana dan prasarana berpengaruh secara signifikan terhadap tingkat kepuasan mahasiswa dengan total pengaruh berturut-turut 0,249; 0,432. sementara aspek kompetensi dosen tidak berpengaruh secara signifikan terhadap tingkat kepuasan mahasiswa dengan total pengaruhnya sebesar 0,149. Sementara tingkat kepuasan mahasiswa berpengaruh secara signifikan terhadap prestasi akademik dengan total pengaruhnya sebesar 0,158.
\end{abstract}

Kata Kunci: Kepuasan Mahasiswa, Perkuliahan Online, PLS-SEM

\section{PENDAHULUAN}

Pembelajaran secara online atau saat ini lebih dikenal dengan istilah pembelajaran dalam jaringan (daring) merupakan solusi terbaik terhadap kegiatan belajar mengajar di tengah pandemi COVID-19. Model pembelajaran ini memberikan kesempatan peserta didik untuk dapat mengikuti suatu pelajaran atau mata kuliah tertentu serta memberikan layanan pembelajaran bermutu yang bersifat masif dan terbuka guna menjangkau peminat yang lebih banyak dan luas. Penyebaran COVID-19 secara global memberikan dampak di segala sektor, tidak terkecuali dalam dunia pendidikan. Indonesia sebagai negara yang salah satu mengalami dampak bencana global pandemi Coronavirus Disease (COVID-19) telah mengambil kebijakan terkait pelaksanaan proses belajar mengajar di seluruh jenjang pendidikan. Kebijakan tersebut tertuang dalam Surat Edaran Nomor 4 Tahun 2020 Menteri Pendidikan dan Kebudayaan Nadiem Anwar Makarim tentang pelaksanaan pendidikan dalam masa darurat Covid-19 (Saragih, 2020). Seperti halnya pembelajaran yang dilakukan secara tatap muka/luring, pembelajaran daring ini memiliki beberapa kendala dalam pelaksanaannya, diantaranya dari kesiapan perangkat elektronik yang dibutuhkan, akses jaringan dan kesiapan peserta didik dalam melakukan adaptasi terhadap model pembelajaran ini.

Penelitian mengenai tingkat kepuasan dan persepsi mahasiswa terhadap perkuliahan online melibatkan beberapa variabel. Variabel-variabel yang digunakan merupakan variabel laten yang tidak dapat diukur secara langsung. Upaya untuk mengetahui tingkat kepuasan dan persepsi mahasiswa terhadap perkuliahan online, Structural Equation Modeling (SEM) merupakan suatu teknik analisis data multivariat yang dapat membantu peneliti untuk menguji hubungan antara variabel laten, variabel indikator dan kesalahan pengukuran secara langsung (Marliana., 2020). Structural Equation Modeling (SEM) merupakan teknik analisis multivariat yang terdiri dari analisis regresi, analisis jalur, dan analisis faktor. Metode SEM memiliki kemampuan analisis dan prediksi yang lebih baik dibandingkan dengan analisis jalur dan analisis regresi karena SEM mampu

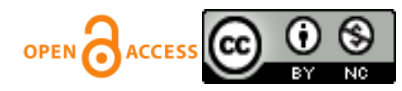


https://jurnal.unsulbar.ac.id/index.php/saintifik

menganalisis lebih dalam dan lebih komprehensif dalam menjelaskan fenomena penelitian. Sementara pada analisis jalur dan analisis regresi hanya mampu mencapai level variabel laten sehingga mengalami kesulitan dalam menganalisis indikator-indikator variabel laten (Ulum M, et al., 2014). Terdapat dua pendekatan yang digunakan dalam SEM yaitu Covariance Based SEM (CB-SEM) dan Partial Least Squares SEM (PLS-SEM) (Halimah, 2017).

Penelitian tentang Partial Least Squares-Structural Equation Modeling (PLS-SEM) pada hubungan antara tingkat kepuasan mahasiswa dan kualitas Google Classroom berdasarkan metode Webqual 4.0 telah dilakukan oleh Marliana (2020). Hasil analisis yang didapatkan menunjukkan bahwa kualitas informasi, kualitas antar muka pengguna dan kualitas interaksi layanan tidak berpengaruh signifikan terhadap tingkat kepuasan mahasiswa sementara variabel usability berpengaruh secara signifikan.

Berdasarkan latar belakang di atas, penulis tertarik untuk melakukan penelitian dengan judul "Partial Least Squares-Structural Equation Modeling (PLS-SEM) pada tingkat kepuasan dan persepsi mahasiswa terhadap perkuliahan online". Penelitian ini dilakukan untuk mengetahui pemodelan Partial Least SquaresStructural Equation Modeling (PLS-SEM) pada kepuasan mahasiswa.

\section{METODE PENELITIAN}

Jenis penelitian yang digunakan merupakan jenis penelitian kuantitatif yaitu menggunakan pendekatan studi literatur. Pendekatan studi literatur pada tahap ini dilakukan identifikasi masalah dengan mencari referensi-referensi yang mendukung penelitian ini, seperti buku, jurnal ilmiah maupun dari sumber-sumber lain yang berkaitan dengan Partial Least Square-Structural Equation Modeling (PLS-SEM). Data yang digunakan dalam penelitian ini merupakan data primer dari hasil survei mengenai tingkat kepuasan dan persepsi mahasiswa terhadap perkuliahan online. Pengumpulan data dilakukan dengan mengambil data populasi Mahasiswa Universitas Sulawesi Barat angkatan 2017, 2018, 2019, dan 2020 dengan jumlah populasi sebnayak 197 Mahasiswa. Hasil survei penelitian dilakukan dengan membagikan angket atau kuesioner kepada responden. Variabel penelitian yang digunakan terdiri dari tiga variabel laten eksogen yang menunjukkan persepsi mahasiswa yaitu aspek pembelajaran $\left(\xi_{i}\right)$, aspek kompetensi dosen $\left(\xi_{2}\right)$, dan aspek sarana dan prasarana $\left(\xi_{3}\right)$ dan dua variabel laten endogen yaitu tingkat kepuasan $\left(\eta_{1}\right)$ dan prestasi akademik $\left(\eta_{2}\right)$.

\subsection{Partial Least Square-Structural Equation Modeling (PLS-SEM)}

Structural Equation Modeling (SEM) merupakan suatu teknik modeling statistik multivariat yang dapat digunakan untuk menguji model-model sebab akibat, yang mana SEM memungkinkan untuk menguji beberapa variabel bebas laten berdasarkan variabel indikatornya. Terdapat dua pendekatan dalam SEM yaitu CB-SEM dan PLS-SEM. Perkembangan Structural Equation Modeling (SEM) berbasis kovarians masih terdapat kelemahan berdasarkan asumsi parametrik yang harus berdistribusi normal dan jumlah sampel yang digunakan harus berkisar antara 200 sampai 800 (Hamid \& Anwar., 2019). Partial Least Square (PLS) pertama kali dikembangkan oleh Herman Wold sebagai metode yang umum digunakan untuk mengestimasi path model yang menggunakan variabel laten berdasarkan indikatornya. Partial Least Square (PLS) merupakan salah satu metode analisis dalam Structural Equation Modeling (SEM) yang powerfull karena dapat diterapkan dalam semua skala data, tidak membutuhkan asumsi dan tidak harus menggunakan sampel dengan jumlah besar (Berutu, et al., 2018).

Tujuan dari Partial Least Square (PLS) adalah untuk memprediksi pengaruh variabel independen $X$ terhadap variabel dependen $Y$ dan menjelaskan ada atau tidaknya hubungan diantara kedua variabel tersebut. Adapun beberapa langkah yang dilakukan dalam pemodelan Partial Least Square-Structural Equation Modeling (PLS-SEM) yaitu sebagai berikut (Riefky \& Hamidah., 2019).

1. Merancang Model Struktural (inner model)

Inner Model menggambarkan hubungan antara variabel laten berdasarkan teori substantif. Dimana hubungan tersebut menggambarkan hubungan antara variabel independen dengan variabel dependen yang kemudian dianalisis menggunakan analisis jalur (Path Analysis) (Riefky \& Hamidah., 2019). Adapun persamaan model struktural (inner model) adalah sebagai berikut: 


$$
\eta_{m \times 1}=\beta_{m \times m} \eta_{m \times 1}+\Gamma_{m \times n} \xi_{n x 1}+\varsigma_{m \times 1}
$$

\section{Keterangan:}

$\eta \quad$ : Matriks konstruk laten endogen $(m x l)$

$\beta$ : Koefisien matriks variabel endogen $(m \times m)$

$\Gamma \quad$ : Matriks konstruk laten eksogen $(m \times n)$

$\xi \quad$ : Koefisien matriks variabel eksogen $(m \times m)$

$\zeta:$ Inner model residual matriks $(n \times l)$

$\mathrm{m}$ : Banyaknya variabel laten eksogen

\section{Merancang Model pengukuran (Outer model)}

Outer model menunjukkan bahwa adanya hubungan antara variabel laten dengan variabel indikatornya secara langsung. Model umum dari outer model dari model indikator refleksif adalah sebagai berikut (Chin., 1998)

Model persamaan pengukuran untuk $x$

$$
\underset{q \times 1}{x}=\underset{q x n}{\Lambda_{n \times 1}} \xi+\underset{q \times 1}{\delta}
$$

Model persamaan pengukuran untuk $y$

$$
\underset{p x 1}{y}=\underset{p x m}{\Lambda_{y}} \underset{p \times 1}{\eta}+\underset{p x 1}{\varepsilon}
$$

dengan :

$$
\begin{array}{ll}
E(\varsigma)=0 & \operatorname{cov}(\varsigma)=\Psi \\
E(\varepsilon)=0 & \operatorname{cov}(\varepsilon)=\theta_{\varepsilon} \\
E(\delta)=0 & \operatorname{cov}(\delta)=\theta_{\delta}
\end{array}
$$

\section{Keterangan:}

$\mathrm{x} \quad$ : vektor bagi peubah indikator eksogen $(q \times 1)$

y : vektor bagi peubah indikator endogen $\left(\begin{array}{lll}p & x & 1\end{array}\right)$

$$
\begin{aligned}
& \Lambda_{x \text { dan }} \Lambda_{y} \text { : matriks bagi loading factor }(\lambda) \\
& \xi \quad \text { : vektor bagi peubah laten eksogen }(n \times 1) \\
& \eta \quad \text { : vektor bagi peubah laten endogen }(m \times l) \\
& \delta \quad \text { : vektor bagi galat pengukuran eksogen }(q x 1)
\end{aligned}
$$

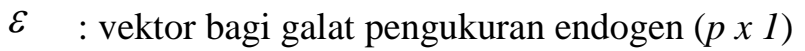

$$
\begin{aligned}
& \mathrm{p} \quad \text { : banyaknya variabel indikator untuk variabel laten endogen } \\
& \text { q : banyaknya variabel indikator untuk variabel laten eksogen }
\end{aligned}
$$

\subsection{Estimasi Parameter Model}

Penaksiran atau estimasi parameter model menggunakan algoritma PLS-SEM yang didasarkan pada metode kuadrat terkecil (OLS) dengan teknik iterasi. Estimasi parameter model PLS-SEM ada tiga tahap yang terdiri dari estimasi bobot (weight estimate) yang digunakan untuk memperoleh skor dari variabel laten, 
estimasi jalur (path estimate) digunakan untuk memperoleh nilai dari koefisien parameter untuk setiap variabel laten, estimasi rata-rata (means) dan lokasi parameter yang merupakan nilai konstanta regresi dari indikator dan variabel lain (Sanchez, 2013).

\subsection{Evaluasi Model}

Evaluasi model pada Partial Least Square-Structural Equation Modeling (PLS-SEM) dibagi menjadi dua tahap yaitu evaluasi model pengukuran (outer model) dan evaluasi model struktural (inner model). Tahapan evaluasi model bertujuan untuk mengetahui bahwa model pengukuran tersebut telah valid dan reliabel (Hamid \& Anwar., 2019).

\section{Outer model}

a. Convergent Validity

Uji validitas indikator reflektif dapat dilihat dari nilai standardized loading faktor $(\lambda)$. Nilai standardized loading factor dikatakan valid jika memiliki nilai diatas 07 (Monika., 2017). Namun demikian untuk penelitian tahap awal dari pengembangan skala pengukuran nilai standardized loading factor diatas 0.5 sampai 0.6 dapat diterima, sedangkan jika nilai standardized loading factor dibawah 0.5 dapat dikeluarkan dari model (Chin., 1998).

\section{b. Composite Reliability}

Composite Reliability untuk menunjukkan keefektifan konstruk yang diukur dengan indikator yang telah ditetapkan. composite reliability dapat dihitung dengan menggunakan persamaan sebagai berikut:

$$
\rho_{c}=\frac{\left(\sum_{k=1}^{K_{j}} \lambda_{j k}\right)^{2}}{\left(\sum_{k=1}^{K_{j}} \lambda_{j k}\right)^{2}+\sum_{k=1}^{K_{j}} \operatorname{var}\left(e_{j k}\right)}
$$

\section{Dengan:}

$$
\begin{array}{ll}
\lambda_{j k} & : \text { loading factor } \\
e_{j k} & : \text { error pengukuran } \\
\operatorname{var}\left(e_{j k}\right) & : \text { variansi dari error pengukuran }
\end{array}
$$

Composite Reliability mempunyai rentang nilai 0 sampai 1, apabila semakin tinggi nilai yang diperoleh maka semakin tinggi tingkat reliabilitasnya dan nilai Composite Reliability harus lebih besar dari 0.708 (Marliana., 2020)

\section{Inner model}

Inner model dievaluasi menggunakan $R^{2}$ untuk konstruk dependen. Nilai $R^{2}$ sama halnya dengan nilai $R^{2}$ dalam analisis regresi linear yaitu besarnya variability variabel endogen yang mampu dijelaskan oleh variabel eksogen. Adapun persamaan $R^{2}$ adalah sebagai berikut (Chin., 1998) 


$$
R^{2}=\sum_{k=1}^{K} \hat{\beta}_{j k} \operatorname{cor}\left(X_{j k}, Y_{j}\right)
$$

Nilai $R^{2}$ mempunyai rentang nilai yaitu 0 sampai dengan 1 yang apabila semakin tinggi nilai maka akan semakin tinggi pula nilai akurasi prediksi model yang diperoleh dengan kriteria 0. 75 (kuat), 0.50 (moderate), 0.25 (lemah) (Hamid \& Anwar., 2019). Selain melihat nilai dari $R^{2}$ untuk evaluasi model, model PLS juga dievaluasi dengan melihat $Q$-square predictive relevance $\left(Q^{2}\right)$ prediktif relevansi oleh model dan juga estimasi parameternya. Nilai $Q^{2}>0$ menunjukkan bahwa model tersebut memiliki predictive relevance (model sudah baik), sedangkan jika nilai $Q^{2} \leq 0$ menunjukkan bahwa model tersebut kurang memiliki predictive relevance (model kurang baik). Adapun perhitungan $Q^{2}$ dilakukan dengan persamaan berikut.

$Q^{2}=1-\left(1-R_{1}^{2}\right)\left(1-R_{2}^{2}\right) \ldots\left(1-R_{n}^{2}\right)$

$R_{1}{ }^{2}, R_{2}{ }^{2} \ldots R_{n}{ }^{2}$ adalah $R^{2}$ variabel endogen. $Q^{2}$ memiliki nilai rentang $0<Q^{2}<1$, apabila nilai $Q^{2}$ semakin mendekati 1 maka akan semakin baik (Supandi \& S., 2020).

\section{Pengujian Hipotesis}

a. Hipotesis untuk outer model

$H_{0}: \lambda_{i}=0$ (indikator ke- $i$ tidak signifikan dalam mengukur variabel laten)

$H_{1}: \lambda_{i} \neq 0$ (indikator ke- $i$ signifikan dalam mengukur variabel laten)

Statistik uji:

$$
t_{\text {hit }}=\frac{\lambda_{i}}{S E\left(\lambda_{i}\right)}
$$

b. Hipotesis untuk inner model

$H_{0}: \gamma_{i}=0$ (variabel eksogen ke-i tidak signifikan dalam mengukur variabel endogen)

$H_{1}: \gamma_{i} \neq 0$ (variabel eksogen ke- $i$ tidak signifikan dalam mengukur variabel endogen)

$t_{\text {hit }}=\frac{\gamma_{i}}{S E\left(\gamma_{i}\right)}$

\section{HASIL DAN PEMBAHASAN}

Data yang digunakan dalam penelitian ini merupakan data primer dari hasil survei mengenai tingkat kepuasan dan persepsi mahasiswa terhadap perkuliahan online. Pengumpulan data dilakukan dengan mengambil data populasi Mahasiswa Universitas Sulawesi Barat angkatan 2017, 2018, 2019, dan 2020. Hasil survei penelitian dilakukan dengan membagikan angket atau kuesioner kepada responden. Diagram jalur menjelaskan pola hubungan antara variabel laten dengan indikator-indikatornya, hubungan antar variabel latennya, serta notasi-notasi koefisien model sehingga mempermudah peneliti untuk melihat model. Berikut ini adalah hasil konstruksi diagram jalur yang dapat dilihat pada Gambar 1 sebagai berikut. 


\section{a. Convergent Validity}

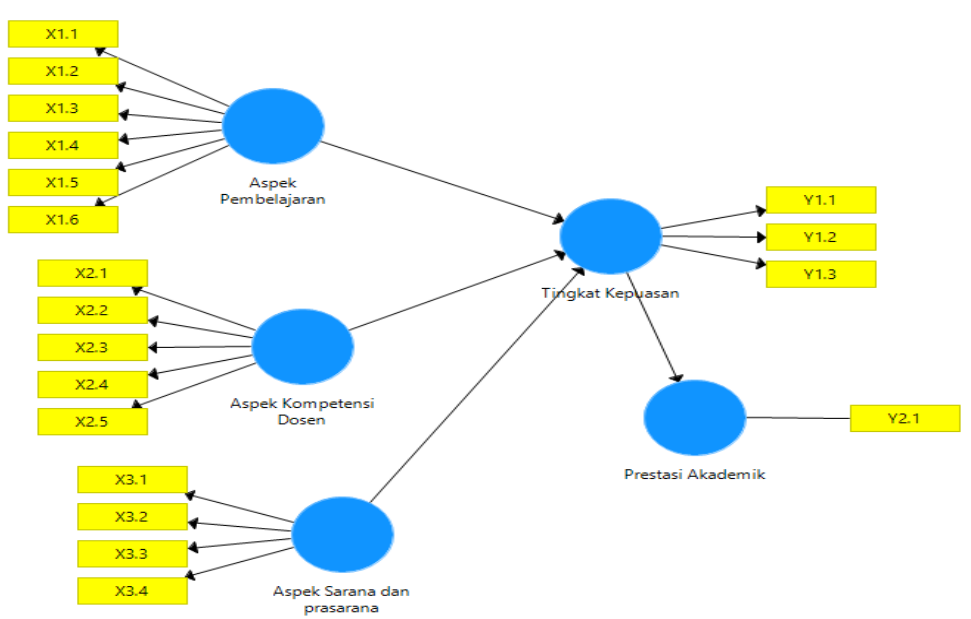

Gambar 1 Konstruksi Diagram Jalur

Nilai loading factor dapat dikatakan valid jika $\lambda \geq 0.5$. Namun jika nilai loading factor berada dibawah 0.5 maka indikator dikatakan tidak valid dan harus dikeluarkan dari analisis karena hal ini mengindikasikan bahwa indikator tersebut tidak cukup baik digunakan untuk mengukur variabel laten. Berikut adalah hasil convergent validity yang dapat dilihat pada tabel Tabel 2 sebagai berikut.

Tabel 2. Convergent Validity

\begin{tabular}{|c|c|c|}
\hline Variabel laten & $\begin{array}{c}\text { Indikato } \\
\text { r }\end{array}$ & $\begin{array}{c}\text { Loading } \\
\text { Factor }\end{array}$ \\
\hline \multirow{4}{*}{ Aspek Pembelajaran } & $\mathrm{X} 1.1$ & 0.645 \\
\cline { 2 - 3 } & $\mathrm{X} 1.2$ & 0.587 \\
\cline { 2 - 3 } & $\mathrm{X} 1.3$ & 0.672 \\
\cline { 2 - 3 } & $\mathrm{X} 1.4$ & 0.758 \\
\cline { 2 - 3 } & $\mathrm{X} 1.5$ & 0.658 \\
\cline { 2 - 3 } & $\mathrm{X} 1.6$ & 0.718 \\
\hline \multirow{4}{*}{ Aspek Kompetensi Dosen } & $\mathrm{X} 2.1$ & 0.858 \\
\cline { 2 - 3 } & $\mathrm{X} 2.2$ & -0.017 \\
\cline { 2 - 3 } & $\mathrm{X} 2.3$ & 0.860 \\
\cline { 2 - 3 } & $\mathrm{X} 2.4$ & 0.792 \\
\cline { 2 - 3 } & $\mathrm{X} 2.5$ & 0.830 \\
\hline \multirow{4}{*}{ Aspek Sarana dan } & $\mathrm{X} 3.1$ & 0.889 \\
\cline { 2 - 3 } Prasarana & $\mathrm{X} 3.2$ & 0.875 \\
\cline { 2 - 3 } & $\mathrm{X} 3.3$ & 0.641 \\
\cline { 2 - 3 } & $\mathrm{X} 3.4$ & 0.045 \\
\hline \multirow{4}{*}{ Tingkat Kepuasan } & $\mathrm{Y} 1.1$ & 0.805 \\
\cline { 2 - 3 } & $\mathrm{Y} 1.2$ & 0.801 \\
\cline { 2 - 3 } & $\mathrm{Y} 1.3$ & 0.804 \\
\hline Prestasi Akademik & $\mathrm{Y} 2.1$ & 1.000 \\
\hline
\end{tabular}

Berdasarkan pada Tabel 2 dapat lihat bahwa terdapat indikator yang tidak valid pada variabel laten aspek kompetensi dosen yaitu $X_{2.2}$ dan aspek sarana dan prasarana yaitu $X_{3.4}$ karena memiliki nilai loading factor $<0.5$. Adapun indikator yang tidak valid tersebut satu per satu dikeluarkan dari model. 
https://jurnal.unsulbar.ac.id/index.php/saintifik

Tabel 3 Convergent Validity (Iterasi 2)

\begin{tabular}{|c|c|c|}
\hline \multirow{4}{*}{ Variabel laten } & $\begin{array}{c}\text { Indikato } \\
\mathrm{r}\end{array}$ & $\begin{array}{c}\text { Loading } \\
\text { Factor }\end{array}$ \\
\hline \multirow{4}{*}{ Aspek Pembelajaran } & $\mathrm{X} 1.1$ & 0.645 \\
\cline { 2 - 3 } & $\mathrm{X} 1.2$ & 0.587 \\
\cline { 2 - 3 } & $\mathrm{X} 1.3$ & 0.672 \\
\cline { 2 - 3 } & $\mathrm{X} 1.4$ & 0.758 \\
\cline { 2 - 3 } & $\mathrm{X} 1.5$ & 0.658 \\
\cline { 2 - 3 } & $\mathrm{X} 1.6$ & 0.718 \\
\hline \multirow{4}{*}{ Aspek Kompetensi Dosen } & $\mathrm{X} 2.1$ & 0.858 \\
\cline { 2 - 3 } & $\mathrm{X} 2.3$ & 0.860 \\
\cline { 2 - 3 } & $\mathrm{X} 2.4$ & 0.792 \\
\cline { 2 - 3 } & $\mathrm{X} 2.5$ & 0.830 \\
\cline { 2 - 3 } & $\mathrm{X} 3.1$ & 0.889 \\
\hline \multirow{4}{*}{ Aspek Sarana dan } & $\mathrm{X} 3.2$ & 0.875 \\
\cline { 2 - 3 } Prasarana & $\mathrm{X} 3.3$ & 0.641 \\
\cline { 2 - 3 } & $\mathrm{X} 3.4$ & 0.045 \\
\hline \multirow{4}{*}{ Tingkat Kepuasan } & $\mathrm{Y} 1.1$ & 0.805 \\
\cline { 2 - 3 } & $\mathrm{Y} 1.2$ & 0.801 \\
\cline { 2 - 3 } & $\mathrm{Y} 1.3$ & 0.804 \\
\hline Prestasi Akademik & $\mathrm{Y} 2.1$ & 1.000 \\
\hline
\end{tabular}

Tabel 4 Convergent Validity (Iterasi 3)

\begin{tabular}{|c|c|c|}
\hline Variabel laten & $\begin{array}{c}\text { Indikato } \\
\mathrm{r}\end{array}$ & $\begin{array}{c}\text { Loading } \\
\text { Factor }\end{array}$ \\
\hline \multirow{4}{*}{ Aspek Pembelajaran } & $\mathrm{X} 1.1$ & 0.645 \\
\cline { 2 - 3 } & $\mathrm{X} 1.2$ & 0.586 \\
\cline { 2 - 3 } & $\mathrm{X} 1.3$ & 0.672 \\
\cline { 2 - 3 } & $\mathrm{X} 1.4$ & 0.758 \\
\cline { 2 - 3 } & $\mathrm{X} 1.5$ & 0.658 \\
\cline { 2 - 3 } & $\mathrm{X} 1.6$ & 0.718 \\
\hline \multirow{4}{*}{ Aspek Kompetensi Dosen } & $\mathrm{X} 2.1$ & 0.858 \\
\cline { 2 - 3 } & $\mathrm{X} 2.3$ & 0.860 \\
\cline { 2 - 3 } & $\mathrm{X} 2.4$ & 0.792 \\
\cline { 2 - 3 } & $\mathrm{X} 2.5$ & 0.830 \\
\hline \multirow{4}{*}{ Aspek Sarana dan } & $\mathrm{X} 3.1$ & 0.888 \\
\cline { 2 - 3 } Prasarana & $\mathrm{X} 3.2$ & 0.869 \\
\cline { 2 - 3 } & $\mathrm{X} 3.3$ & 0.655 \\
\hline \multirow{4}{*}{ Tingkat Kepuasan } & $\mathrm{Y} 1.1$ & 0.805 \\
\cline { 2 - 3 } & $\mathrm{Y} 1.2$ & 0.800 \\
\cline { 2 - 3 } & $\mathrm{Y} 1.3$ & 0.805 \\
\hline Prestasi Akademik & $\mathrm{Y} 2.1$ & 1.000 \\
\hline
\end{tabular}


Setelah mengeluarkan variabel indikator yang tidak valid pada variabel laten aspek kompetensi dosen, masih terdapat indikator yang tidak valid pada variabel laten aspek sarana dan prasarana yaitu $X_{3.4}$ karena memiliki nilai loading factor $<0.5$ sehingga indikator tersebut dikeluarkan dari model. Sehingga dapat dilihat pada tabel 4 berikut.

Berdasarkan tabel 4. dapat dilihat bahwa setelah mengeluarkan variabel indikator yang tidak valid pada variabel aspek sarana dan prasarana, semua nilai loading factor pada setiap indikator dari kelima variabel laten telah bernilai $\geq 0.5$. Sehingga dapat disimpulkan bahwa convergent validity dari setiap indikator telah valid dalam mengukur variabel laten karena nilai loading factor telah terpenuhi.

\section{b. Composite Reliability}

Composit Reliability digunakan untuk menguji nilai reliabilitas indikator-indikator pada suatu variabel. Suatu variabel dikatakan reliabel apabila Composit Reliability memiliki nilai lebih besar dari 0.7. hasil composit reliability dapat dilihat pada Tabel 5 berikut

Tabel 5. Hasil Pengujian Composite Reliability

\begin{tabular}{|l|c|}
\hline \multicolumn{1}{|c|}{ Variabel Laten } & Reliabilitas Komposit \\
\hline Aspek Pembelajaran & 0.833 \\
\hline Aspek kompetensi Dosen & 0.902 \\
\hline Aspek Sarana dan Prasarana & 0.850 \\
\hline Tingkat Kepuasan & 0.845 \\
\hline Prestasi Akademik & 1.000 \\
\hline
\end{tabular}

Tabel 5 menunjukkan bahwa nilai Composite Reliability telah memenuhi syarat karena memiliki nilai lebih dari 0.7 .

Pengujian Hipotesis:

$H_{0}$ : Hubungan antara aspek pembelajaran terhadap tingkat kepuasan mahasiswa tidak berpengaruh signifikan

$H_{1}$ : Hubungan antara aspek pembelajaran terhadap tingkat kepuasan mahasiswa berpengaruh signifikan

$H_{0} \quad$ : Hubungan antara aspek kompetensi dosen terhadap tingkat kepuasan mahasiswa tidak berpengaruh signifikan

$H_{1}$ : Hubungan antara aspek kompetensi dosen terhadap tingkat kepuasan mahasiswa berpengaruh signifikan

$H_{0} \quad$ : Hubungan antara aspek sarana dan prasarana terhadap tingkat kepuasan mahasiswa tidak berpengaruh signifikan

$H_{1} \quad$ : Hubungan antara aspek sarana dan prasarana terhadap tingkat kepuasan mahasiswa berpengaruh signifikan

$H_{0}$ : Hubungan antara tingkat kepuasan mahasiswa terhadap prestasi akademik tidak berpengaruh signifikan

$H_{1}$ : Hubungan antara tingkat kepuasan mahasiswa terhadap prestasi akademik berpengaruh signifikan

Partial Least Square-Structural Equation Modeling pada Tingkat Kepuasan dan Persepsi Mahasiswa terhadap Perkuliahan Online (Suriana, dkk) 
https://jurnal.unsulbar.ac.id/index.php/saintifik

Tingkat signifikansi $\alpha$ yang digunakan adalah 5\% sehingga nilai $t_{\text {tabel }}=1.96$. Hasil pengujian $t$ statistics pada model struktural (inner model) dapat dilihat pada Tabel 6 berikut.

Tabel 6. Pengujian hipotesis inner model

\begin{tabular}{|l|c|c|}
\hline \multicolumn{1}{|c|}{ Variabel Laten } & $\begin{array}{c}\text { Original } \\
\text { Sample }\end{array}$ & T Statistik \\
\hline Aspek Pembelajaran $\rightarrow$ Tingkat Kepuasan & 0.249 & 3.100 \\
\hline Aspek Kompetensi Dosen $\rightarrow$ Tingkat Kepuasan & 0.149 & 1.614 \\
\hline Aspek Sarana dan prasarana $\rightarrow$ Tingkat Kepuasan & 0.432 & 3.554 \\
\hline Tingkat Kepuasan $\rightarrow$ Prestasi Akademik & 0.158 & 2.579 \\
\hline
\end{tabular}

Tabel 6 menunjukkan bahwa aspek pembelajaran dan aspek sarana dan prasarana memiliki hubungan yang signifikan terhadap tingkat kepuasan mahasiswa karena memiliki nilai $t$-statistic > $t_{\text {tabel }}=1.96$ sedangkan aspek kompetensi dosen tidak berpengaruh secara signifikan terhadap tingkat kepuasan mahasiswa karena memiliki nilai $t$-statistic $<t_{\text {tabel }}=1.96$ sementara tingkat kepuasan mahasiswa berpengaruh secara signifikan terhadap prestasi akademik karena memiliki nilai $t$-statistic $>t_{\text {tabel }}=1.96$. Sehingga diperoleh model struktural sebagai berikut.

$$
\begin{aligned}
& \eta_{1}=0.249 \xi_{1}+0.149 \xi_{2}+0.432 \xi_{3}+\zeta_{1} \\
& \eta_{2}=0.158 \eta_{1}+\zeta_{2}
\end{aligned}
$$

Model penyesuaian yang diperoleh memiliki nilai $R^{2}$ pada variabel laten endogen tingkat kepuasan sebesar 0.544 yang berarti bahwa variasi tingkat kepuasan dapat dijelaskan sebesar 0.544 oleh variabel laten aspek pembelajaran, aspek kompetensi dosen, dan aspek sarana dan prasarana, sedangkan nilai koefisien determinasi pada variabel laten prestasi akademik sebesar 0.025 yang berarti bahwa variasi prestasi akademik dapat dijelaskan sebesar 0.025 oleh variabel tingkat kepuasan. Selain $R^{2}$ juga dapat dilihat nilai $Q^{2}$ yang

\begin{tabular}{|c|c|c|}
\hline \multicolumn{3}{|c|}{ Tabel 7 Nilai $R^{2}$ dan $Q^{2}$ Skema Path PLS } \\
\hline Variabel Laten & R Square & $Q^{2}$ \\
\hline Tingkat Kepuasan & 0.544 & \multirow{2}{*}{0.297} \\
\hline Prestasi Akademik & 0.025 & \\
\hline
\end{tabular}
dapat dilihat pada tabel 7.

\section{KESIMPULAN}

Model Partial Least Square-Structural Equation Modeling (PLS-SEM) dalam menentukan tingkat kepuasan dan persepsi mahasiswa terhadap perkuliahan online yaitu:

$$
\begin{aligned}
& \eta_{1}=0.249 \xi_{1}+0.149 \xi_{2}+0.432 \xi_{3}+\zeta_{1} \\
& \eta_{2}=0.158 \eta_{1}+\zeta_{2}
\end{aligned}
$$


https://jurnal.unsulbar.ac.id/index.php/saintifik

Persamaan pada model Partial Least Square-Structural Equation Modeling (PLS-SEM) tersebut menyatakan bahwa tingkat kepuasan $\left(\eta_{1}\right)$ mengalami peningkatan seiring dengan peningkatan aspek

pembelajaran $\left(\xi_{1}\right)$, aspek kompetensi dosen $\left(\xi_{2}\right)$, aspek sarana dan prasarana $\left(\xi_{3}\right)$ dengan kontribusi masingmasing 0.265 ; 0.013 dan 0.536 dan satu untuk setiap satu satuan. Sedangkan jika variabel tingkat kepuasan bertambah sebesar satu satuan, maka akan menambah variabel prestasi akademik $\left(\eta_{2}\right)$ sebesar 0.158. Variabel aspek pembelajaran dan aspek sarana dan prasarana berpengaruh signifikan terhadap tingkat kepuasan, sedangkan aspek kompetensi dosen tidak berpengaruh secara signifikan. Tingkat kepuasan mahasiswa berpengaruh signifikan terhadap prestasi akademik.

\section{DAFTAR PUSTAKA}

Berutu, T. G., et al, 2018, Analisis Kepuasan dan Loyalitas Pelanggan dalam Pemesanan Tiket Pesawat Secara Online Menggunakan pendekatan Partial Least Square (PLS), Jurnal Gaussian, No. 4, Vol. 7, Hal. 361 372.

Chin, W. W., 1998, The Partial Least Squares Approach to Structural Equation Modeling, Marcoulides, G. A., Modern Methods For business Research, Lawrence Erlbaum Associates, London.

Halimah, S. N., 2017, Analisis Pengaruh Kuliatas Layanan dan Kepuasan Terhadap Loyalitas Pasien di Medical Center ITS dengan Metode Structural Equation Modeling - Partial least Square (SEM-PLS), Skripsi, Program Pasca Sarjana Departemen Statistika, Univ. ITS, Surabaya.

Hamid, R. S., \& Anwar, S. M. 2019. Structural Equation Modeling (SEM) Berbasis Varian (Konsep Dasar dan Aplikasi Program Smart PLS 3.2.8. dalam Riset Bisnis), PT Inkubator Penulis Indonesia: Jakarta Pusat

Marliana, R. R., 2020, Partial Least Squares-Structural Equation Modeling pada Tingkat Kepuasan dan Persepsi Mahasiswa Terhadap Perkuliahan Online, Jurnal Matematika, Statistika, dan Komputasi, No.2, Vol.16, 174-186, : https://journal.unhas.ac.id/index.php/jmsk/article/view/7851

Riefky, M, Hamidah, W. N, 2019, Pemodelan SEM PLS pada Faktor-Faktor yang Mempengaruhi Kepuasan Layanan Mahasiswa Fakultas Ekonomi UNIPA Surabaya, Seminar Nasional Hasil Riset dan pengabdian, ke-II, Surabaya, 18 Oktober.

Sanchez, $\quad$ G, 2013, PLS Path Modeling With http://www.gastonsanchez.com/PLS_Path_Modeling_With_R.pdf, diakses tanggal 20 Februari 2021.

Supandi, E. D \& S, S. S., 2020, Pengaruh Remunerasi dan Motivasi terhadap Kinerja pegawai UIN Sunan Kalijaga Yogyakarta dengan Menggunakan Structural Equation Modeling, PRISMA, Prosiding Seminar Nasional Matematika, Semarang, 28 Februari.

Saragih O, et al., 2020, Persepsi Mahasiswa terhadap Pembelajaran Daring Selama Pandemi Covid-19, Jurnal Penelitian Pendidikan \& Pembelajaran, No. 3, Vol. 7, Hal. 1-14.

Ulum M, et al., 2014, Analisis Structural Equation Modeling (SEM) untuk Sampel Kecil dengan menggunakan Partial Least Square (PLS), Prosiding Seminar Nasional matematika, jember, 19 November. 